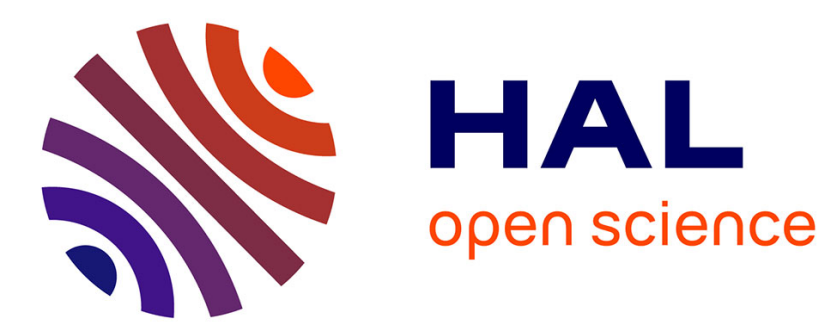

\title{
A study of the daily feed intake pattern in sheep fed orchard grass hay or silage ad libitum
}

René Baumont, V Chiofalo, Jp Dulphy

\section{To cite this version:}

René Baumont, V Chiofalo, Jp Dulphy. A study of the daily feed intake pattern in sheep fed orchard grass hay or silage ad libitum. Annales de zootechnie, 1993, 42 (2), pp.188-188. hal-00888922

\section{HAL Id: hal-00888922 \\ https://hal.science/hal-00888922}

Submitted on 1 Jan 1993

HAL is a multi-disciplinary open access archive for the deposit and dissemination of scientific research documents, whether they are published or not. The documents may come from teaching and research institutions in France or abroad, or from public or private research centers.
L'archive ouverte pluridisciplinaire HAL, est destinée au dépôt et à la diffusion de documents scientifiques de niveau recherche, publiés ou non, émanant des établissements d'enseignement et de recherche français ou étrangers, des laboratoires publics ou privés. 


\title{
A study of the daily feed intake pattern in sheep fed orchard grass hay or silage ad libitum
}

\author{
R Baumont, V Chiofalo, JP Dulphy
}

INRA, unité Ingestion, station de recherches sur la Nutrition des herbivores, centre de Clermont-Ferrand/Theix, 63122 Saint-Genès-Champanelle, France

The mechanisms involved in the control of intake of grass silages are still not well known (Dulphy and Demarquilly, 1991). In order to better understand differences in daily voluntary intake $(\mathrm{VI})$, the daily intake patterns were compared for the same plant harvested either as hay or as silage.

Six wethers $(60 \mathrm{~kg})$ were fed ad libitum once daily orchard grass harvested at the same date, either as hay $(H$; organic matter digestibility $(\mathrm{OMd})=64.3)$, as fine chopped silage without preservative $(\mathrm{S}, \mathrm{OMd}=64.3$ ) or with the addition of formic acid (SA, OMd =67.9) according to two $3 \cdot 3$ latin-square designs. The daily evolution in intake was recorded for 5-8 d per sheep and per forage as described by Baumont et al (1990). Results were expressed as DM intake for each of the $24 \mathrm{~h}$. To determine the hours which explain differences in VI, the 24-h patterns $(n=119)$ were submitted to a factorial discriminant analysis with the effect of the nature of forage (3 levels).

VI differed significantly between $\mathrm{H}, \mathrm{SA}$ and S (1 469a, 1 241b and 1 054b g DM respectively; $a \neq b, P<0.05)$. Factorial discriminant analysis revealed that the larger intake of hay was mainly related to the 2 nd $h$ post-feeding (10:00) and to the period from 15:00 to $19: 00 \mathrm{~h}$ (fig 1). The intakes during these hours were well correlated to the 1st axis of the analysis which explained $89.2 \%$ of the total variance. $83.2 \%$ of the patterns were automatically well classified by the analysis. During the 1st $h$ post-feeding the silages were eaten as well as the hay. This may indicate that palatability is not the causative factor of their lower intake. However, some satiation signals may act more strongly during the 2 nd $h$ and later on with grass silage, causing its lower level of intake compared to hay.

Acknowledgments - The authors thank $P$ Faverdin for discussing the method of analysis.

Dulphy JP, Demarquilly C (1991) In: Proc Conf Forage Conservation Towards 2000 (Honig H, Pahlow G, eds) Landbauforschung Volkenrode, Germany, 140-161

Baumont R, Séguier N, Dulphy JP (1990) J Agric Sci Camb 115, 277-284

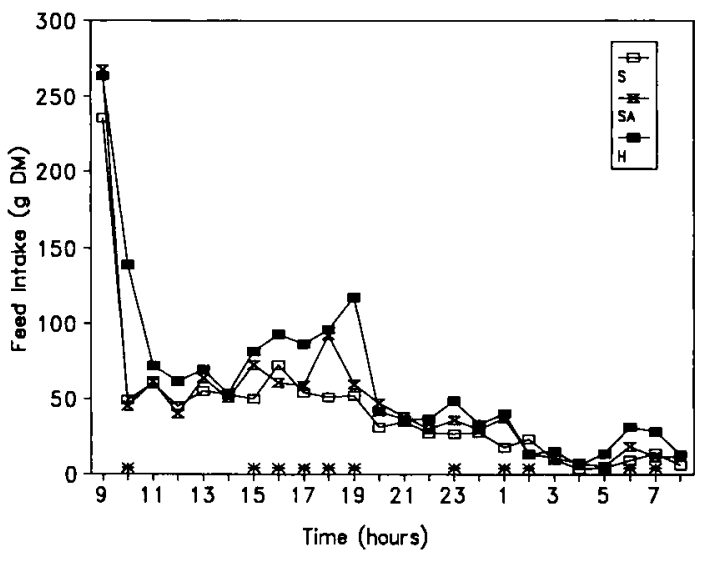

Fig 1. Intake patterns of 6 sheep fed orchard grass either as hay $(H)$, or as silage without preservative (S) or with formic acid (SA). The asterisks indicate the hours during which intake was significantly different between forages $(P<$ 0.05). 